\title{
Yield and Quality of Carrot Cultivars with Eight Nitrogen Rates and Best Management Practices
}

\author{
Robert Conway Hochmuth, Marina Burani-Arouca, and \\ Charles Edward Barrett \\ North Florida Research and Education Center-Suwannee Valley, \\ University of Florida, 7580 County Road 136, Live Oak, FL 32060
}

Additional index words. Daucus carota, Four Rs Principles, plant nutrition, plant tissue nitrogen, nitrogen leaching

\begin{abstract}
Carrot (Daucus carota) production has increased in North Florida and South Georgia since 2015. Deep sandy soils, moderate winter climate, availability of irrigation water, and proximity to eastern markets are favorable for carrot production in the region. Nitrogen $(N)$ is required for successful carrot production, and the current recommended $N$ application rate in Florida is $196 \mathrm{~kg} \cdot \mathrm{ha}^{-1}$. The objective of this study was to verify the recommended $N$ rate for the sandy soils of North Florida using current industry standard cultivars and practices. Carrot cultivars for the whole carrot fresh market, Choctaw and Maverick, and cultivars for the cut-and-peel market, Triton and Uppercut 25, were direct seeded on 102-cm-wide pressed bed tops on 29 Oct. 2016 and 2 Nov. 2017 in Live Oak, FL. Eight $N$ application rates $(56,112,168,224,280,336,392$, and 448 $\mathrm{kg} \cdot \mathrm{ha}^{-1}$ ) were tested, and all $\mathrm{N}$ applications were placed on the bed top. $\mathrm{N}$ rates were split and timed to increase $\mathbf{N}$ use efficiency. Regression analyses were used to determine the optimal $\mathbf{N}$ rate for carrots in North Florida. A quadratic plateau regression for both seasons combined indicated $206 \mathrm{~kg} \cdot \mathrm{ha}^{-1} \mathrm{~N}$ was the optimal rate for carrots, with marketable yield of $71.3 \mathrm{Mg} \cdot \mathrm{ha}^{-1}$, regardless of cultivar. All four cultivars attained acceptable yield including Uppercut 25, which exhibited significant foliage damage following freezing temperatures. This study resulted in updated information on best management practices for carrot production in Florida, especially nutrient stewardship.
\end{abstract}

Historically, the United States has been a net importer of fresh or chilled carrots [U.S. Department of Agriculture (USDA), 2019a]. The average annual fresh market carrot production in the United States between 2008 and 2018 was 1.32 million tons (USDA, $2019 b$ ). Florida carrot production has primarily been for the fresh market, and the production area more than doubled between 2007 and 2017, totaling 1722 ha (USDA, 2019c). Florida carrots have historically been grown on high organic matter soils (muck soils) in Central and South Florida. Muck soils require very low nitrogen $(\mathrm{N})$ inputs, whereas carrot production on sandy soils requires higher $\mathrm{N}$ inputs. Most of the Florida carrot production

Received for publication 5 May 2021. Accepted for publication 14 June 2021.

Published online 14 September 2021.

We thank Ben Broughton, Mike Boyette, and the entire farm crew at the North Florida Research and Education Center-Suwannee Valley for their expert execution of the field trials; the growers who provided feedback, project support, and insights; and the Florida Department of Agricultural and Consumer Services, Office of Agricultural Water Policy, for funding this project. We also thank Dr. George Hochmuth, Dr. Lincoln Zotarelli, and Gary England for their guidance in the preparation of this publication.

R.C.H. is the corresponding author. E-mail: bobhoch@ufl.edu.

This is an open access article distributed under the CC BY-NC-ND license (https://creativecommons. org/licenses/by-nc-nd/4.0/). on muck soils stopped in 1998 when the state purchased almost 8000 ha of environmentally sensitive farmland in the Zellwood area around Lake Apopka, where much of the carrot production area was located (Mangrum, 2016; Orlando Sentinel, 1985). After carrot production in the Zellwood, FL, area stopped, some carrot production was initiated in the North Florida and South Georgia area but remained relatively small until 2015. In 2015, as a result of California water shortages in carrot production areas, two large California carrot producers began purchasing land and carrot processing infrastructure in North Florida and South Georgia to increase production in the Southeastern United States. This region has several favorable characteristics to support a significant increase in carrot production area. The region has a moderate winter climate, availability of large tracts of agricultural land with deep sandy soils, highquality groundwater for irrigation, proximity to a large agricultural allied industry with input suppliers, and ready access to large consumer markets on the east coast.

North Florida's deep sandy soils are suitable for production of carrots but are also vulnerable to nutrient loss, especially $\mathrm{N}$, from leaching. The 2018 proposal and pending adoption of a Basin Management Action Plan (BMAP) for much of the Suwannee River Basin of North Florida (FDEP, 2018), has led University of Florida research and Extension faculty to evaluate $\mathrm{N}$ management strategies aimed at reducing $\mathrm{N}$ loss off farm. The adoption of a BMAP in a region makes it mandatory for farmers to implement best management practices (BMPs) and to reach the recommended nutrient application rates or implement a water quality monitoring program on-farm (FDACS, 2015). The impairment to the water bodies in this BMAP area has been identified as $\mathrm{N}$ which has guided the focus of this research. Carrot has a relatively high $\mathrm{N}$ requirement and very little research has been conducted on carrots in North Florida sandy soils therefore, it has become a high priority to determine the current BMPs for $\mathrm{N}$ use in carrot production for the Florida Department of Agriculture and Consumer Services, FL Department of Environmental Protection, and the Suwannee River Water Management District.

Nitrogen is often the most limiting nutrient in sandy soils, and the current recommended $\mathrm{N}$ rate for carrots in Florida is $196 \mathrm{~kg} \cdot \mathrm{ha}^{-1}$ (Liu et al., 2019). This recommendation for carrots was based on one Florida study completed in the 1990s (Hochmuth et al., 1999) combined with other research on carrots grown in similar soils but in areas outside Florida. Current production practices are somewhat different from those used in past research trials. Because carrot production is relatively new to North Florida and the current recommendation may be obsolete, in part for not reflecting the needs of new cultivars, increased plant populations, different bed and row configurations, irrigation management, and fertigation technologies that may differ in sandy soils. The objectives of this study were to determine the optimum $\mathrm{N}$ rate for carrot grown in the sandy soils of North Florida using BMPs, demonstrate existing N BMPs for carrots in the region, and to evaluate common commercial cultivars for both the whole and cut-and-peel carrot markets.

\section{Materials and Methods}

Field trials were conducted at the University of Florida, North Florida Research and Education Center-Suwannee Valley in Live Oak, FL. The soil series was characterized as Hurricane - Sandy, siliceous, thermic Oxyaquic Alorthods (Weatherspoon, 2006), a typical soil type used for carrot production in North Florida. The soil was prepared and fumigated before planting. The soil fumigant Telone II (1,3-dichloropropene, Corteva, Wilmington, DE) was applied at $168 \mathrm{~L} \cdot \mathrm{ha}^{-1}$ or $199 \mathrm{~kg} \cdot \mathrm{ha}^{-1}$ a.i., on 9 Sept. 2016 (2017 season) and on 13 Oct. 2017 (2018 season) at 30.5 to $35.6 \mathrm{~cm}$ below the soil surface. After fumigation, the soil was irrigated with $12 \mathrm{~mm}$ of water to improve fumigant efficacy. Rye windbreaks were seeded in the spray alleys to reduce damage from wind-blown sand

Dolomitic lime was applied, at a rate of $2242 \mathrm{~kg} \cdot \mathrm{ha}^{-1}$ both seasons. Boron was applied at $1.12 \mathrm{~kg} \cdot \mathrm{ha}^{-1}$ on 19 Oct. 2016 and 27 Oct. 2017, and Sul-Po-Mag (0N-0P-18.3K-22S$11 \mathrm{Mg}$ ) was applied at a rate of $448 \mathrm{~kg} \cdot \mathrm{ha}^{-1}$ on 20 Oct. 2016 and 27 Oct. 2017. These fertilizer applications were broadcast applied to the entire field based on soil test results. Applications of preplant fertilizer $13 \mathrm{~N}-1.8 \mathrm{P}-10.8 \mathrm{~K}$ (2017 
season) and $14 \mathrm{~N}-1.8 \mathrm{P}-11.6 \mathrm{~K}$ (2018 season) were banded in a $102-\mathrm{cm}$-wide band to the soil surface at $215 \mathrm{~kg} \cdot \mathrm{ha}^{-1}$ (2017 season) and 202 $\mathrm{kg} \cdot \mathrm{ha}^{-1}$ (2018 season) and rototilled into the top $15 \mathrm{~cm}$ to provide $28 \mathrm{~kg} \cdot \mathrm{ha}^{-1} \mathrm{~N}$. The soil was then pressed into beds that were $102 \mathrm{~cm}$ wide and $10 \mathrm{~cm}$ high using a bed press implement. Beds were spaced $183 \mathrm{~cm}$ center to center to prevent contamination of $\mathrm{N}$ treatments between beds. The trials were arranged in a split-plot design with randomized complete blocks and four replications.

Main plot. The main plot factor was Nfertilizer application rate.

In both the 2017 and 2018 seasons, eight $\mathrm{N}$ rates were tested in increments of 56 $\mathrm{kg} \cdot \mathrm{ha}^{-1} \mathrm{~N}$, resulting in rates of $56,112,168$, $224,280,336,392$, and $448 \mathrm{~kg} \cdot \mathrm{ha}^{-1} \mathrm{~N}$. The schedule for each $\mathrm{N}$ application was chosen to provide the best distribution of $\mathrm{N}$ during the season based on plant growth stage (Table 1). For the 336,392 , and $448 \mathrm{~kg} \cdot \mathrm{ha}^{-1} \mathrm{~N}$ rates, weekly applications were made beginning 27 Dec. 2017 and 28 Dec. 2018 to avoid crop damage from excess fertilizer at crop establishment. In-season $\mathrm{N}$ rate treatment applications were made using ammonium nitrate ( $32 \mathrm{~N}-0 \mathrm{P}-0 \mathrm{~K})$ applied to the $102-\mathrm{cm}$ bed top with a single hopper fertilizer drop spreader (First Products, Tifton, GA), designed for two rows, with four directional spouts modified to apply an even distribution of fertilizer to the single $102 \mathrm{~cm}$ bed top. Fertilizer rates were calculated using the linear bed foot method (Hochmuth and Hanlon, 2012) for a bed spacing of $132 \mathrm{~cm}$, which is more typical on commercial farms. The linear bed foot method was used to normalize fertilizer rates between commercial and research bed width differences. All $\mathrm{N}$ fertilizer, preplant, and top-dress applications were made to the 102 $\mathrm{cm}$ bed area only.

Two broadcast applications of Sul-Po-Mag $(0 \mathrm{~N}-0 \mathrm{P}-18.3 \mathrm{~K}-22 \mathrm{~S}-11 \mathrm{Mg})$ at rate of $258 \mathrm{~kg} \cdot \mathrm{ha}^{-1}$ were made both seasons on 19 Jan. and 2 Feb. 2017 and on 22 Jan. and 16 Feb. 2018 , resulting in $56 \mathrm{~kg} \cdot \mathrm{ha}^{-1}$ of potash in each application. Thus, the total potash applied including all preplant and in-season applications was 211 and $226 \mathrm{~kg} \cdot \mathrm{ha}^{-1}$ for the 2017 and 2018 seasons, respectively. In addition, $52 \mathrm{~kg} \cdot \mathrm{ha}^{-1}$ of triple super phosphate $(0 \mathrm{~N}-19.8 \mathrm{P}-0 \mathrm{~K})$ was applied to the bed top on 22 Jan. 2018 to accommodate grower input after the 2017 season and to ensure that phosphorus was not a limiting factor.

Subplot. The subplot factor was carrot cultivar. The four carrot cultivars grown in this study were Choctaw (Nunhems USA, Inc., Parma, ID), Maverick (Nunhems USA, Inc.), Triton (Sakata Seed America, Inc., Morgan Hill, CA), and Uppercut 25 (Nunhems USA, Inc.). These cultivars were selected for this trial in consultation with local growers. 'Choctaw' was also selected because previous Florida research was conducted on the cultivar. 'Choctaw' and 'Maverick' are larger carrots used for the fresh-pack whole carrot (cello type) market, whereas 'Triton' and 'Uppercut 25 ' are smaller diameter carrots used for the cut-and-peel or snack product market.

The cultivars were direct seeded on 29 Oct. 2016 and on 2 Nov. 2017. Carrots were mechanically seeded using a Seed Spider planter (Sutton Agricultural Enterprises, Inc., Salinas, CA). The planter placed the seed in four rows spaced $4.76 \mathrm{~cm}$ apart and $0.64 \mathrm{~cm}$ deep, then pressed the soil on the bed top firmly with a roller. The final carrot row configuration was two sets of four rows with $30.5 \mathrm{~cm}$ between sets, on a $102 \mathrm{~cm}$ pressed bed top. Subplots were $15 \mathrm{~m}$ long and consisted of four beds, one per cultivar, in each $\mathrm{N}$ rate main plot.

Plant stand counts were taken in the 2017 season $45 \mathrm{~d}$ after plant emergence to better estimate final plant populations. Final plant populations, in plants per hectare, were 992,827 for 'Choctaw', 849,331 for 'Maverick', 1,648,279 for 'Triton', and 2,496,123 for 'Uppercut 25' in the 2017 season. Final plant populations in 2018 were estimated at $1,160,494$ for 'Choctaw', 1,135,802 for 'Maverick', 2,098,765 for 'Triton', and 2,098,765 for 'Uppercut 25'. Target plant populations were provided by local producers using these cultivars, and final plant stands were similar to the target populations. The only adjustment in target population was made for the cultivar Uppercut 25, which was reduced by $\approx 15 \%$ in the 2018 season to follow the same adjustment area producers made to increase carrot diameter for that cultivar.

Growing conditions. Cultural practices along with pest and disease management strategies consistent with grower practices were implemented both seasons. The primary disease of concern was Alternaria leaf blight, which is caused by the fungal agent Alternaria dauci (Farrar et al., 2004). Alternaria can directly impact yield by reducing the photosynthetic leaf area and can limit mechanical harvesting

Table 1. Nitrogen application schedule per $\mathrm{N}$ rate treatment for the 2017 and 2018 growing seasons. Top dressing applications are shown by application date and days after planting (DAP).

2017 season

28 Nov. 13 Dec. 20 Dec. 27 Dec. 3 Jan. 10 Jan. 17 Jan. 24 Jan. 31 Jan. 7 Feb. 14 Feb. 20 Feb. 28 Feb. 7 Mar. 14 Mar. 21 Mar.

DAP

\begin{tabular}{|c|c|c|c|c|c|c|c|c|c|c|c|c|c|c|c|c|}
\hline & 30 & 45 & 52 & 59 & 66 & 73 & 80 & 87 & 94 & 101 & 108 & 114 & 122 & 129 & 136 & 143 \\
\hline Total $\mathrm{N}$ rate $^{\mathrm{z}}$ & \multicolumn{16}{|c|}{ Nitrogen applications $\left(\mathrm{kg} \cdot \mathrm{ha}^{-1}\right)$} \\
\hline 56 & 11.9 & & & & & & & & & & & 16.1 & & & & \\
\hline 224 & 24.5 & & 24.5 & & & 24.5 & & 24.5 & & 24.5 & & 24.5 & & 24.5 & & 24.5 \\
\hline 280 & 31.5 & & 31.5 & & & 31.5 & & 31.5 & & 31.5 & & 31.5 & & 31.5 & & 31.5 \\
\hline 336 & 20.5 & 20.5 & & 20.5 & 20.5 & 20.5 & 20.5 & 20.5 & 20.5 & 20.5 & 20.5 & 20.5 & 20.5 & 20.5 & 20.5 & 20.5 \\
\hline
\end{tabular}

2018 season

4 Dec. 18 Dec. 21 Dec. 28 Dec. 4 Jan. 11 Jan. 16 Jan. 25 Jan. 1 Feb. 8 Feb. 13 Feb. 22 Feb. 1 Mar. 8 Mar. 13 Mar. 22 Mar. DAP

\begin{tabular}{|c|c|c|c|c|c|c|c|c|c|c|c|c|c|c|c|c|}
\hline \multirow[b]{3}{*}{ Total $\mathrm{N}$ rate $^{\mathrm{z}}$} & \\
\hline & 32 & 46 & 49 & 56 & 63 & 70 & 75 & 84 & 91 & 98 & 103 & 112 & 119 & 126 & 131 & 140 \\
\hline & \multicolumn{16}{|c|}{ Nitrogen applications $\left(\mathrm{kg} \cdot \mathrm{ha}^{-1}\right)$} \\
\hline 56 & & 9.3 & & & & & & 9.3 & & & & & & 9.3 & & \\
\hline 224 & 24.5 & & 24.5 & & & 24.5 & & 24.5 & & 24.5 & & 24.5 & & 24.5 & & 24.5 \\
\hline 280 & 31.5 & & 31.5 & & & 31.5 & & 31.5 & & 31.5 & & 31.5 & & 31.5 & & 31.5 \\
\hline 336 & 20.5 & 20.5 & & 20.5 & 20.5 & 20.5 & 20.5 & 20.5 & 20.5 & 20.5 & 20.5 & 20.5 & 20.5 & 20.5 & 20.5 & 20.5 \\
\hline
\end{tabular}

${ }^{\mathrm{z}}$ The total $\mathrm{N}$ rate for the season (kilograms per hectare) includes a preplant application of $28 \mathrm{~kg} \cdot \mathrm{ha}^{-1}$ of $\mathrm{N}$ for all treatments. 
because this fungus can cause $50 \%$ leaf loss (Paret, 2019). This disease was managed by weekly fungicide applications during weather conditions conducive to disease development using recommended rotations of chemical classes. The primary weed species were cutleaf evening primrose (Oenothera laciniate) and wild mustard (Sinapis arvensis). Two postemergence applications of linuron-based herbicide Lorox DF (NovaSource, Phoenix, AZ), 1 week apart, were made beginning at the fourleaf stage of the carrots, resulting in satisfactory weed control with no observed damage to the carrot plants.

Irrigation was applied using a low pressure, overhead, linear move system (Valmont Industries Inc., Valley, NE). Volumetric soil moisture was monitored using two soil moisture sensors (EnviroSCAN; Sentek, Stepney, Australia) placed in the 224 and $392 \mathrm{~kg} \cdot \mathrm{ha}^{-1}$ rate plots of 'Uppercut 25'. These sensors read soil moisture at 10-, 20-, 30-, 40-, and $50-\mathrm{cm}$ depths. Interpretation of moisture movement through the soil profile enabled accurate scheduling and delivery of irrigation during the growing seasons. The carrot irrigation schedule developed for North Florida was used to irrigate the crop (Sharma et al., 2020). Irrigation was initially applied at a rate of $4 \mathrm{~mm}$ to germinate the seeds and to reduce wind erosion. As the crop grew, irrigation was increased to $10 \mathrm{~mm}$. Irrigation events were triggered to prevent soil moisture depletion below $50 \%$ plant available water. Air temperature, growing degree days, rainfall, and solar radiation were collected from a Florida Automated Weather Network (www. fawn.ifas.ufl.edu) weather station located within $100 \mathrm{~m}$ of the experiment site.

Plant performance parameters. Cold injury was quantified by ratings using the Horsfall-Barratt semiquantitative scale and visual assessment as described by Francis (2013). Horsfall and Barratt (1945) proposed a grading system for measuring plant disease severity that is based on $50 \%$ as a midpoint and the grades differ by a factor of two in either direction. This scale ranges from 1 to 12 , one being the lowest rating (no infection) and 12 being $100 \%$ infection. Using the Horsfall-Barratt method can minimize human error in interpreting the percentage of foliage damaged. Observations were triggered if observed air temperatures were $-1.11^{\circ} \mathrm{C}$ or below, and cold injury ratings were taken if injuries were apparent. Cold injury ratings were taken on 16 Mar. 2017 and 15 Mar. 2018 within $24 \mathrm{~h}$ of cold injury occurrence.

Samples of fully expanded, most recently matured leaves were submitted for leaf tissue $\mathrm{N}$ analysis on two occasions in each season: on 10 Feb. and 14 Mar. 2017 and on 7 Feb. and 15 Mar. 2018. Each sample consisted of at least 25 complete leaves, blade and petiole. Samples were submitted to Waters Agricultural Laboratories (Camilla, GA) where the plant tissue was processed and analyzed for total Kjeldahl N (reported as percent N). Plant height was taken in each plot 1 week before harvest by measuring the plant foliage height for five randomly selected, representative plants within each plot.

Yield and carrot quality characteristics. Carrots were harvested based on predicted harvest date from local growers, primarily in conjunction with target size ranges for 'Choctaw' and 'Maverick'. When the target date was approaching, a few carrots per treatment were sampled for a general assessment of the percentage of carrots that reached marketable length and width to verify the selected harvest date was correct. Harvests were carried out on 10 and 11 Apr. 2017 and 19 and 20 Apr. 2018. Carrots were loosened from the soil by undercutting the beds with a metal undercutter blade on a three-point hitch. The undercutter was lowered $\approx 38 \mathrm{~cm}$ below the top of the bed. A 6-m subplot in the center of each 15-m plot was used for yield data collection. The carrots were hand-pulled from the 6$\mathrm{m}$ subplot, tops were removed by hand, and carrots were bagged in the field. Total harvested weight (kilogram) per subplot was measured and recorded. Individual carrot weights, diameter at the top of the carrot, length of carrot, and a total weight of 15 randomly selected carrots from each plot each year were recorded on the same day as harvest. From these data, the grade of each carrot was determined using
2017 season
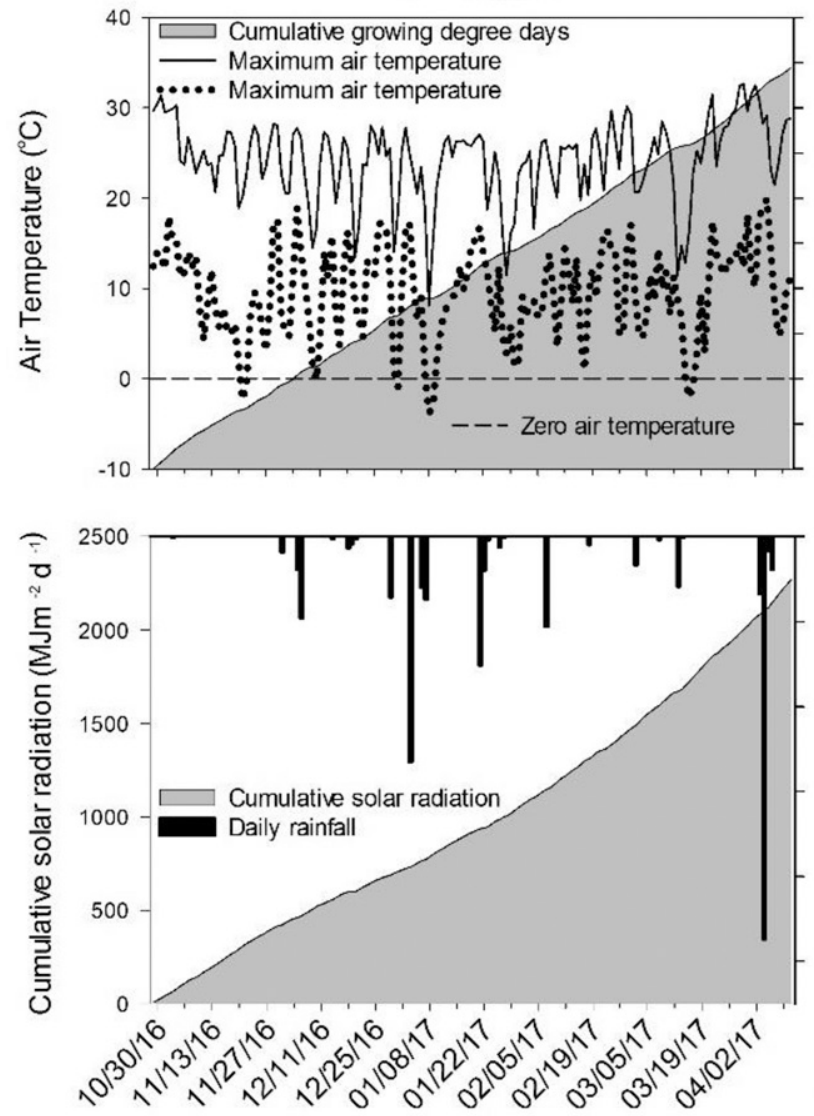

2018 season
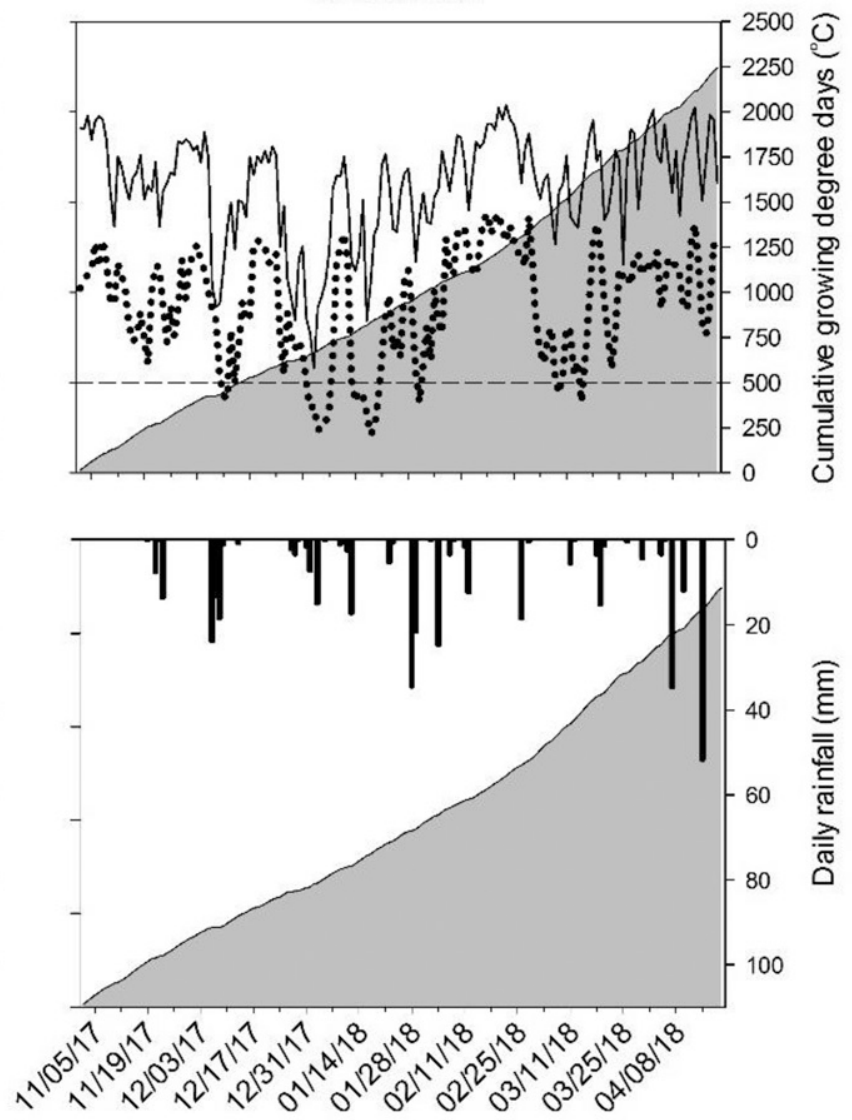

Fig. 1. Maximum and minimum air temperatures with cumulative growing degree days (base temperature $3.33^{\circ} \mathrm{C}$ ) and cumulative solar radiation with daily rainfall for 2017 and 2018 growing seasons in Live Oak, FL. 
the USDA (1965) grades and standards for topped carrots.

Statistical analysis. Data were analyzed using the Generalized Linear Mixed Model, Regression, and Nonlinear Regression Procedures of SAS (SAS Version 9.4; SAS Inst. Inc., Cary, NC). A two-way analysis of variance was performed for yield and carrot quality data to determine significance of main effects and presence of interaction between $\mathrm{N}$ rate and cultivar. Regression analysis was used to determine whether a linear or quadratic relationship existed for $\mathrm{N}$ rate treatments. Data from both seasons were pooled if there was no year by treatment interaction and for the quadradic plateau analysis.

\section{Results and Discussion}

Growing season weather. Weather was generally favorable for carrot production in both seasons with relatively dry weather conditions and low disease pressure. The growing season trends of maximum and minimum air temperatures with cumulative growing degree days and daily rainfall with daily, weekly, and cumulative solar radiation for both 2017 and 2018 growing seasons are shown in Fig. 1. Rainfall was similar during both seasons. Cumulative growing degree days were similar for both years with 4029 in the 2017 season and 3664 in the 2018 season.

Cold injury ratings. There were significant positive linear and quadradic responses to cold injury seen with increasing $\mathrm{N}$ rates both years (Table 2). During the 2017 season, the lowest recorded air temperature was $-3.72{ }^{\circ} \mathrm{C}$ (Fig. 1) on 8 Jan. 2017, $71 \mathrm{~d}$ after planting (DAP). Cold injury ratings were taken on 16 Mar. 2017 and 4.5 to 5.8 (12\% to $25 \%$ foliage damage) were recorded in plants with 168 , $224,280,336,392$, and $448 \mathrm{~kg} \cdot \mathrm{ha}^{-1} \mathrm{~N}$ in comparison with plants fertilized with 56 and $112 \mathrm{~kg} \cdot \mathrm{ha}^{-1} \mathrm{~N}$ that were rated at 4.0 and 4.2 , respectively ( $6 \%$ to $12 \%$ foliage damage) in 2017. Although there were significant responses to $\mathrm{N}$ rate treatments, the differences were biologically insignificant, and no crop loss was recorded from cold injury. During the 2018 season, the lowest recorded air temperature was $-5.72^{\circ} \mathrm{C}$ on 18 Jan. 2018 (77 DAP) during 6 consecutive nights, with air temperatures reaching less than $-2.22^{\circ} \mathrm{C}$, but very minor cold injury was observed (data not shown). Cold injury to carrot foliage was observed and recorded after a late cold event on 15 Mar. 2018 (133 DAP) when air temperature reached a min of $-2.17^{\circ} \mathrm{C}$ and plants treated with $448 \mathrm{~kg} \cdot \mathrm{ha}^{-1} \mathrm{~N}$ were rated at 5.1 ( $12 \%$ to $25 \%$ foliage damage). The cultivar Choctaw had statistically lower injury ratings compared with all other varieties in both seasons, and in 2018, Choctaw showed virtually no foliage damage from cold injury (Table 3 ). The cultivar Uppercut 25 showed statistically higher foliage damage when compared with all other cultivars in 2017 and had the highest injury rating of all cultivars, 6.9 rating, at $25 \%$ to $50 \%$ foliage damage.

Leaf $N$ concentration and plant height. A positive trend in leaf $\mathrm{N}$ concentration was

Table 2. Effect of $\mathrm{N}$ fertilization rate on cold injury foliage ratings, leaf $\mathrm{N}$ concentration, plant height, and total marketable yield for the 2017 and 2018 growing seasons.

\begin{tabular}{|c|c|c|c|c|c|}
\hline \multirow[b]{2}{*}{ Treatment } & \multirow[b]{2}{*}{$\begin{array}{c}\text { Cold injury } \\
\text { rating }^{\mathrm{z}}\end{array}$} & \multicolumn{2}{|c|}{ Leaf nitrogen $(\% \mathrm{~N})$} & \multirow[b]{2}{*}{ Plant Ht $(\mathrm{cm})$} & \multirow[b]{2}{*}{$\begin{array}{c}\text { Marketable } \\
\text { yield }\left(\mathrm{Mg} \cdot \mathrm{ha}^{-1}\right)\end{array}$} \\
\hline & & $\begin{array}{c}\text { First } \\
\text { sampling }\end{array}$ & $\begin{array}{c}\text { Second } \\
\text { sampling }\end{array}$ & & \\
\hline \multicolumn{6}{|c|}{ Season 2017} \\
\hline \multicolumn{6}{|c|}{$\overline{\text { Nitrogen rate }\left(\mathrm{kg} \cdot \mathrm{ha}^{-1}\right)}$} \\
\hline 56 & 4.0 & 2.8 & 3.0 & 20.2 & 31.0 \\
\hline 112 & 4.2 & 3.2 & 2.8 & 29.0 & 55.2 \\
\hline 168 & 5.8 & 3.8 & 3.1 & 34.0 & 69.7 \\
\hline 224 & 4.5 & 3.9 & 3.1 & 34.5 & 71.8 \\
\hline 280 & 5.4 & 3.9 & 3.2 & 33.6 & 70.1 \\
\hline 336 & 5.8 & 4.1 & 3.4 & 33.8 & 71.9 \\
\hline 392 & 5.8 & 4.2 & 3.4 & 32.7 & 73.1 \\
\hline 448 & 5.6 & 4.1 & 3.4 & 32.8 & 70.0 \\
\hline \multicolumn{6}{|c|}{ Significance } \\
\hline $\mathrm{L}^{\mathrm{w}}$ & $<0.0001$ & $<0.0001$ & $<0.0001$ & $<0.0001$ & $<0.0001$ \\
\hline Q & $<0.0001$ & $<0.0001$ & $<0.0001$ & $<0.0001$ & $<0.0001$ \\
\hline \multicolumn{6}{|c|}{ Season 2018} \\
\hline \multicolumn{6}{|c|}{ Nitrogen rate $\left(\mathrm{kg} \cdot \mathrm{ha}^{-1}\right)$} \\
\hline $56^{\circ}$ & 1.7 & 3.5 & 2.7 & 27.9 & 47.4 \\
\hline 112 & 2.1 & 4.0 & 2.7 & 34.0 & 59.5 \\
\hline 168 & 2.7 & 4.2 & 2.8 & 39.2 & 71.5 \\
\hline 224 & 2.3 & 4.3 & 3.0 & 38.3 & 72.5 \\
\hline 280 & 2.0 & 4.3 & 3.2 & 39.5 & 74.5 \\
\hline 336 & 2.4 & 4.4 & 3.3 & 38.6 & 72.7 \\
\hline 392 & 3.4 & 4.6 & 3.3 & 38.4 & 68.6 \\
\hline 448 & 5.1 & 4.5 & 3.3 & 35.7 & 66.5 \\
\hline \multicolumn{6}{|c|}{ Significance } \\
\hline $\mathrm{L}^{\mathrm{w}}$ & $<0.0001$ & $<0.0001$ & $<0.0001$ & $<0.0001$ & $<0.0001$ \\
\hline Q & $<0.0001$ & $<0.0001$ & $<0.0001$ & $<0.0001$ & $<0.0001$ \\
\hline
\end{tabular}

${ }^{\mathrm{z}}$ Ratings are based on the Horsfall-Barratt scale, with 1 representing virtually no damage and 12 representing 100\% of damage. Ratings were taken on 16 Mar. 2017 and 15 Mar. 2018.

${ }^{\mathrm{y}}$ First sample for leaf $\mathrm{N}$ concentration was at 104 and at $97 \mathrm{~d}$ after planting (DAP) for the 2017 and 2018 seasons, respectively.

${ }^{\mathrm{x}}$ Second sample for leaf $\mathrm{N}$ concentration was at 136 and at 133 DAP for the 2017 and 2018 seasons, respectively.

${ }^{\mathrm{w}} \mathrm{L}=$ linear; $\mathrm{Q}=$ quadratic; $P<0.05$.

observed in both seasons as $\mathrm{N}$ rates increased (Table 2). Despite the statistically significant response to $\mathrm{N}$ application rate, measured leaf $\mathrm{N}$ concentrations were above the current recommendation in all $\mathrm{N}$ rates for Florida grown

Table 3. Effect of carrot cultivar on cold injury foliage ratings, leaf $\mathrm{N}$ concentration, plant height, and total marketable yield for the 2017 and 2018 growing seasons.

\begin{tabular}{|c|c|c|c|c|c|}
\hline \multirow[b]{2}{*}{ Treatment } & \multirow[b]{2}{*}{$\begin{array}{l}\text { Cold injury } \\
\text { rating }\end{array}$} & \multicolumn{2}{|c|}{ Leaf nitrogen $(\% \mathrm{~N})$} & \multirow[b]{2}{*}{ Plant $\mathrm{ht}^{\mathrm{z}}(\mathrm{cm})$} & \multirow[b]{2}{*}{$\begin{array}{c}\text { Marketable } \\
\text { yield }^{\mathrm{z}}\left(\mathrm{Mg} \cdot \mathrm{ha}^{-1}\right)\end{array}$} \\
\hline & & $\begin{array}{c}\text { First } \\
\text { sampling }^{\mathrm{x}}\end{array}$ & $\begin{array}{c}\text { Second } \\
\text { sampling }^{\mathrm{w}}\end{array}$ & & \\
\hline \multicolumn{6}{|c|}{ Season 2017} \\
\hline \multicolumn{6}{|l|}{ Cultivar } \\
\hline Choctaw & $3.6 \mathrm{c}$ & $3.7 \mathrm{ab}$ & $3.3 \mathrm{a}$ & $30.6 \mathrm{~b}$ & 63.6 NS \\
\hline Maverick & $5.0 \mathrm{~b}$ & $3.9 \mathrm{a}$ & $3.3 \mathrm{a}$ & $28.8 \mathrm{c}$ & 63.6 NS \\
\hline Triton & $5.0 \mathrm{~b}$ & $3.7 \mathrm{ab}$ & $3.1 \mathrm{ab}$ & $32.4 \mathrm{a}$ & $63.7 \mathrm{NS}$ \\
\hline Uppercut 25 & $6.9 \mathrm{a}$ & $3.7 \mathrm{~b}$ & $3.0 \mathrm{~b}$ & $33.5 \mathrm{a}$ & $65.5 \mathrm{NS}$ \\
\hline \multicolumn{6}{|c|}{ Season 2018} \\
\hline \multicolumn{6}{|l|}{ Cultivar } \\
\hline Choctaw & $1.3 \mathrm{~b}$ & $4.1 \mathrm{NS}$ & $3.1 \mathrm{NS}$ & $35.4 \mathrm{~b}$ & $59.5 \mathrm{c}$ \\
\hline Maverick & $2.9 \mathrm{a}$ & $4.3 \mathrm{NS}$ & $3.1 \mathrm{NS}$ & $33.7 \mathrm{~b}$ & $65.6 \mathrm{~b}$ \\
\hline Triton & $3.2 \mathrm{a}$ & $4.2 \mathrm{NS}$ & $2.9 \mathrm{NS}$ & $37.5 \mathrm{a}$ & $75.0 \mathrm{a}$ \\
\hline Uppercut 25 & $3.4 \mathrm{a}$ & $4.2 \mathrm{NS}$ & $3.0 \mathrm{NS}$ & $39.2 \mathrm{a}$ & $66.5 \mathrm{~b}$ \\
\hline
\end{tabular}

${ }^{\mathrm{z}}$ Values followed by the same letter within a column indicate means are not significantly different $(P \leq$ $0.05)$ with means separation by Tukey-Kramer test. NS indicates no significant difference between means. ${ }^{\mathrm{y}}$ Ratings are based on the Horsfall-Barratt scale, with 1 representing virtually no damage and 12 representing $100 \%$ of damage. Ratings were taken on 16 Mar. 2017 and 15 Mar. 2018.

${ }^{\mathrm{x}}$ First sample for leaf $\mathrm{N}$ concentration was at 104 and at $97 \mathrm{~d}$ after planting (DAP) for the 2017 and 2018 seasons, respectively.

${ }^{\mathrm{w}}$ Second sample for leaf $\mathrm{N}$ concentration was at 136 and at 133 DAP for the 2017 and 2018 seasons, respectively. 
consistent across sampling dates and between years. There was no interaction between $\mathrm{N}$ rate and cultivar for leaf $\mathrm{N}$ concentrations. These results are consistent with studies conducted in Canada, where no significant differences in $\mathrm{N}$ uptake were seen between carrot cultivars grown in mineral soils (Westerveld et al., 2006b). Westerveld et al. (2006b, 2007) have documented the deep-rooted nature of carrots, their ability to scavenge mineralized and deep soil N (Westerveld et al., 2006a), and no single $\mathrm{N}$ rate is applicable in mineral soils in all years (Westerveld et al., 2006c). The two seasons in the current study had relatively dry conditions with minimal $\mathrm{N}$ leaching potential; therefore, low $\mathrm{N}$ application rates were still able to maintain healthy plant tops. However, maintaining a healthy carrot top requires maintaining adequate disease control and providing sufficient plant nutrition. In years with increased rainfall, $\mathrm{N}$ leaching could lead to a reduction in carrot top health in low $\mathrm{N}$ application rates. Maintaining a healthy carrot top (foliage) and at least 15 to $20 \mathrm{~cm}$ of foliage for top-lifter type harvesters is important because these harvesters lift the carrot crop out of the ground by the plant's leaves, which is the dominant harvest practice in North Florida.

Plant height showed a significant positive trend with increasing $\mathrm{N}$ rate (Table 2). There were significant differences in plant heights among the cultivars (Table 3). Plant height was greater in 'Triton' and 'Uppercut 25' than 'Choctaw' or 'Maverick' in both seasons. Although there were significant differences in plant height, carrots from all $\mathrm{N}$ treatments and from all cultivars were sufficient to allow for mechanical harvest with a top lifter carrot harvester. There was no interaction between $\mathrm{N}$ rate and cultivar for carrot height. In the 2 years of this study, carrot tops could be harvested for all $\mathrm{N}$ rates but without adequate disease control, the lowest $\mathrm{N}$ rate of $56 \mathrm{~kg} \cdot \mathrm{ha}^{-1} \mathrm{~N}$ would have been at greater risk of insufficient height or unhealthy tops.

Carrot quality characteristics. The USDA established quality grades and standards for topped carrots and each carrot sold under U.S. Extra No. 1 and U.S. No.1 must have a diameter of not less than $1.91 \mathrm{~cm}$ or more than 3.81 $\mathrm{cm}$, and a length not less than $12.7 \mathrm{~cm}$ (USDA, 1965). Both whole carrot cultivars Choctaw and Maverick achieved a marketable diameter across all $\mathrm{N}$ rates in 2017 and 2018 (Table 4). The cut-and-peel cultivars Triton and Uppercut 25 did not reach $1.91 \mathrm{~cm}$ of diameter when fertilized with 56,112 , and $448 \mathrm{~kg} \cdot \mathrm{ha}^{-1} \mathrm{~N}$ in 2017, and the same was confirmed for Uppercut 25 when fertilized with $56 \mathrm{~kg} \cdot \mathrm{ha}^{-1} \mathrm{~N}$ in 2018 (Table 4). The cultivars Triton and Uppercut 25 were smaller, as expected, for optimal cut-and-peel types. Although the cut-and-peel cultivars did not meet the $1.91 \mathrm{~cm}$ diameter at the lowest $\mathrm{N}$ rate, cut-and-peel cultivars are not held to the same fresh market standards as the whole carrot cultivars. All cultivars across all $\mathrm{N}$ rate treatments were longer than the $12.7 \mathrm{~cm}$ necessary to meet the USDA standard, with the exception of Choctaw, Triton, and Uppercut 25 when fertilized with $56 \mathrm{~kg} \cdot \mathrm{ha}^{-1} \mathrm{~N}$ (Table 5). In general, carrot individual weights were lower in the cut-and-peel cultivars compared with the

Table 4. Interaction effect of $\mathrm{N}$ fertilization rate and carrot cultivar on carrot diameter.

\begin{tabular}{|c|c|c|c|c|}
\hline \multirow[b]{3}{*}{ Treatment } & \multicolumn{4}{|c|}{ Carrot diam $(\mathrm{cm})$} \\
\hline & \multicolumn{2}{|c|}{ Whole cultivars } & \multicolumn{2}{|c|}{ Cut-and-peel cultivars } \\
\hline & Choctaw & Maverick & Triton & Uppercut 25 \\
\hline & \multicolumn{4}{|c|}{ Season 2017} \\
\hline \multicolumn{5}{|c|}{ Nitrogen rate $\left(\mathrm{kg} \cdot \mathrm{ha}^{-1}\right)$} \\
\hline 56 & 2.38 & 2.23 & 1.80 & 1.58 \\
\hline 112 & 3.16 & 2.75 & 2.15 & 1.83 \\
\hline 168 & 3.30 & 2.94 & 2.17 & 2.09 \\
\hline 224 & 3.27 & 2.78 & 2.14 & 1.99 \\
\hline 280 & 2.78 & 2.92 & 2.26 & 2.00 \\
\hline 336 & 3.01 & 2.86 & 2.18 & 2.04 \\
\hline 392 & 2.99 & 3.01 & 2.29 & 1.92 \\
\hline 448 & 2.97 & 2.88 & 2.08 & 1.87 \\
\hline \multicolumn{5}{|l|}{ Significance } \\
\hline $\mathrm{L}^{\mathrm{z}}$ & NS & 0.001 & 0.001 & 0.002 \\
\hline \multirow[t]{2}{*}{ Q } & 0.0001 & 0.0001 & 0.0001 & 0.002 \\
\hline & \multicolumn{4}{|c|}{ Season 2018} \\
\hline \multicolumn{5}{|c|}{ Nitrogen rate $\left(\mathrm{kg} \cdot \mathrm{ha}^{-1}\right)$} \\
\hline 56 & 2.36 & 2.51 & 2.17 & 1.76 \\
\hline 112 & 2.68 & 2.72 & 2.23 & 1.98 \\
\hline 168 & 3.23 & 2.90 & 2.31 & 2.09 \\
\hline 224 & 2.87 & 2.79 & 2.13 & 2.03 \\
\hline 280 & 2.84 & 2.92 & 2.18 & 2.15 \\
\hline 336 & 2.72 & 2.65 & 2.22 & 2.07 \\
\hline 392 & 2.83 & 2.81 & 2.17 & 2.20 \\
\hline 448 & 2.64 & 2.60 & 2.03 & 1.91 \\
\hline \multicolumn{5}{|c|}{ Significance } \\
\hline $\mathrm{L}^{\mathrm{z}}$ & NS & NS & NS & 0.004 \\
\hline $\mathrm{Q}$ & 0.0001 & 0.0001 & NS & 0.0001 \\
\hline
\end{tabular}

${ }^{\mathrm{z}} \mathrm{L}=$ linear; $\mathrm{Q}=$ quadratic; NS, not significant at $P<0.05$.

whole carrot cultivars (Table 6). In both years, there were significant carrot individual weight responses to $\mathrm{N}$ rate, but the trends were not consistent between years.

Yield. Carrots were harvested based on predicted harvest date from local growers,

Table 5. Interaction effect of $\mathrm{N}$ fertilization rate and carrot cultivar on carrot length.

\begin{tabular}{|c|c|c|c|c|}
\hline \multirow[b]{3}{*}{ Treatment } & \multicolumn{4}{|c|}{ Carrot length $(\mathrm{cm})$} \\
\hline & \multicolumn{2}{|c|}{ Whole cultivars } & \multicolumn{2}{|c|}{ Cut-and-peel cultivars } \\
\hline & Choctaw & Maverick & Triton & Uppercut 25 \\
\hline & \multicolumn{4}{|c|}{ Season 2017} \\
\hline \multicolumn{5}{|c|}{ Nitrogen rate $\left(\mathrm{kg} \cdot \mathrm{ha}^{-1}\right)$} \\
\hline $56^{\circ}$ & 19.1 & 20.3 & 18.2 & 17.4 \\
\hline 112 & 21.8 & 20.4 & 20.3 & 19.8 \\
\hline 168 & 20.6 & 20.9 & 20.2 & 22.1 \\
\hline 224 & 21.7 & 20.3 & 21.0 & 20.6 \\
\hline 280 & 20.7 & 20.6 & 21.4 & 20.3 \\
\hline 336 & 21.2 & 21.4 & 20.4 & 19.8 \\
\hline 392 & 21.6 & 21.8 & 21.6 & 20.8 \\
\hline 448 & 20.1 & 21.4 & 21.1 & 19.7 \\
\hline \multicolumn{5}{|c|}{ Significance } \\
\hline $\mathrm{L}^{\mathrm{z}}$ & NS & NS & NS & NS \\
\hline \multirow[t]{2}{*}{ Q } & NS & NS & NS & NS \\
\hline & \multicolumn{4}{|c|}{ Season 2018} \\
\hline \multicolumn{5}{|c|}{ Nitrogen rate $\left(\mathrm{kg} \cdot \mathrm{ha}^{-1}\right)$} \\
\hline 56 & 18.0 & 20.2 & 19.2 & 20.2 \\
\hline 112 & 20.5 & 21.5 & 20.2 & 21.1 \\
\hline 168 & 23.1 & 21.7 & 19.5 & 21.9 \\
\hline 224 & 21.7 & 21.6 & 20.3 & 22.1 \\
\hline 280 & 21.3 & 22.0 & 20.9 & 23.3 \\
\hline 336 & 20.7 & 20.4 & 21.1 & 23.2 \\
\hline 392 & 20.6 & 22.7 & 21.4 & 23.5 \\
\hline 448 & 21.8 & 20.8 & 20.6 & 20.8 \\
\hline \multicolumn{5}{|c|}{ Significance } \\
\hline $\mathrm{L}^{\mathrm{z}}$ & 0.002 & NS & 0.0001 & NS \\
\hline $\mathrm{Q}$ & 0.0001 & 0.040 & 0.001 & 0.001 \\
\hline
\end{tabular}

primarily, in conjunction with target size ranges for the whole carrot cultivars Choctaw and Maverick. Total yield was considered equivalent to marketable yield because in both seasons more than $95 \%$ of the yield was marketable according to the USDA grades 
Table 6. Interaction effect of $\mathrm{N}$ fertilization rate and carrot cultivar on individual carrot weight.

\begin{tabular}{|c|c|c|c|c|}
\hline \multirow[b]{3}{*}{ Treatment } & \multicolumn{4}{|c|}{ Carrot individual wt $(\mathrm{g})$} \\
\hline & \multicolumn{2}{|c|}{ Whole cultivars } & \multicolumn{2}{|c|}{ Cut-and-peel cultivars } \\
\hline & Choctaw & Maverick & Triton & Uppercut 25 \\
\hline & \multicolumn{4}{|c|}{ Season 2017} \\
\hline \multicolumn{5}{|c|}{ Nitrogen rate $\left(\mathrm{kg} \cdot \mathrm{ha}^{-1}\right)$} \\
\hline 56 & 2.88 & 2.73 & 1.88 & 1.16 \\
\hline 112 & 5.79 & 4.18 & 3.08 & 1.82 \\
\hline 168 & 6.11 & 4.88 & 3.10 & 2.78 \\
\hline 224 & 6.14 & 4.45 & 3.26 & 2.63 \\
\hline 280 & 5.40 & 5.07 & 3.70 & 2.48 \\
\hline 336 & 5.83 & 5.23 & 3.49 & 2.83 \\
\hline 392 & 5.52 & 6.27 & 4.46 & 2.44 \\
\hline 448 & 5.36 & 5.32 & 3.73 & 2.31 \\
\hline \multicolumn{5}{|c|}{ Significance } \\
\hline $\mathrm{L}^{\mathrm{z}}$ & 0.040 & 0.0001 & 0.001 & 0.001 \\
\hline \multirow[t]{2}{*}{ Q } & 0.0001 & 0.0001 & 0.001 & 0.0001 \\
\hline & \multicolumn{4}{|c|}{ Season 2018} \\
\hline \multicolumn{5}{|c|}{ Nitrogen rate $\left(\mathrm{kg} \cdot \mathrm{ha}^{-1}\right)$} \\
\hline 56 & 2.93 & 3.90 & 2.99 & 1.87 \\
\hline 112 & 3.98 & 4.61 & 3.06 & 2.53 \\
\hline 168 & 6.74 & 5.51 & 3.45 & 3.07 \\
\hline 224 & 5.39 & 5.49 & 3.64 & 3.07 \\
\hline 280 & 4.91 & 6.00 & 3.58 & 3.68 \\
\hline 336 & 4.84 & 4.95 & 3.91 & 3.52 \\
\hline 392 & 5.13 & 5.88 & 3.72 & 4.03 \\
\hline 448 & 4.74 & 4.57 & 3.17 & 2.81 \\
\hline \multicolumn{5}{|l|}{ Significance } \\
\hline $\mathrm{L}^{\mathrm{z}}$ & NS & 0.022 & NS & 0.001 \\
\hline Q & 0.0001 & 0.0001 & NS & 0.0001 \\
\hline
\end{tabular}

and standards. The interaction between $\mathrm{N}$ rate and cultivar was not significant for total yield in 2017 and 2018, thus the main effect of $\mathrm{N}$ application rate and carrot cultivar were examined separately. In both seasons, $\mathrm{N}$ rate had a significant positive effect on marketable yield such that plants fertilized with 56 $\mathrm{kg} \cdot \mathrm{ha}^{-1} \mathrm{~N}$ resulted in the lowest yield, followed by plants fertilized with $112 \mathrm{~kg} \cdot \mathrm{ha}^{-1}$ $\mathrm{N}$ (Table 2). In both years, carrots fertilized with $168 \mathrm{~kg} \cdot \mathrm{ha}^{-1} \mathrm{~N}$ or more yielded 66.5 to 74.5 $\mathrm{Mg} \mathrm{ha}^{-1}$, and there was no further increase in yield with additional $\mathrm{N}$ applied.

There were no differences in yield between cultivars in 2017 (Table 3). In 2018, the cutand-peel cultivar Triton yielded the highest, followed by Uppercut 25 and Maverick (Table 3). The whole carrot cultivar Choctaw yielded the lowest at $59.5 \mathrm{Mg} \cdot \mathrm{ha}^{-1}$ yet, yield for all cultivars was within the North Florida industry expected yield of 56.0 to $67.0 \mathrm{Mg} \cdot \mathrm{ha}^{-1}$. Carrot yield reported in this study are higher than yield reported in mineral soils by Hochmuth et al. (1999) and Westerveld et al. (2006c). Some of differences in yield between these studies is most likely the result of differing seeding rates and production practices. In North Florida, plant population has nearly doubled those reported by Hochmuth et al. (1999) where their population target was 555,500 plants/ha and yielded 20.6 to $24.7 \mathrm{Mg} \cdot \mathrm{ha}^{-1}$, compared with $1,234,568$ plants/ha currently.

The 2017 and 2018 carrot growing seasons were similar in both weather and yield; therefore, carrot marketable yield data from both years were combined for an overall regression analysis with all $\mathrm{N}$ applications rates and carrot cultivars to determine the
$\mathrm{Mg} \cdot \mathrm{ha}^{-1}$. This optimal rate was $14 \%$ to $37 \%$ higher than the optimal rates reported by optimal $\mathrm{N}$ rate for these conditions. There was a significant $(P \leq 0.001)$ quadratic plaresponse in marketable yield to $\mathrm{N}$ cation rate (Fig. 2). According to the first derivative of the function, the optimal $\mathrm{N}$ fertilizer application rate was $206 \mathrm{~kg} \cdot \mathrm{ha}^{-1} \mathrm{~N}$ tilizer application rate was $206 \mathrm{~kg}$ ha 1 N
Hochmuth et al. (1999), but the population in the current study was double their population and produced a yield increase of $202 \%$ to $238 \%$ for $\mathrm{N}$ rates above $112 \mathrm{~kg} \cdot \mathrm{ha}^{-1} \mathrm{~N}$. The high plant population bed configuration now used in North Florida is more productive than the system used more than 20 years ago and requires more $\mathrm{N}$ to maintain this higher level of productivity. However, yield was not increased with $\mathrm{N}$ application rates above 168 to $224 \mathrm{~kg} \cdot \mathrm{ha}^{-1}$. Hamilton and Bernier (1975) reported carrot $\mathrm{N}$ uptake of $213.6 \mathrm{~kg} \cdot \mathrm{ha}^{-1}$, suggesting that the optimal rate of 206 $\mathrm{kg} \cdot \mathrm{ha}^{-1} \mathrm{~N}$ is sufficient in mineral soils where little $\mathrm{N}$ is supplied from soil mineralization. The $206 \mathrm{~kg} \cdot \mathrm{ha}^{-1} \mathrm{~N}$ rate may not be sufficient in years with leaching rainfall events or when production constraints prevent efficient $\mathrm{N}$ application methods as were used in this study, i.e., all fertilizer was applied only to the bed tops using a drop spreader and nearly weekly applications during carrot development. Frequent applications over the entire season until a couple weeks from harvest is supported by Westerveld et al. (2006a), who reported $\mathrm{N}$ uptake by carrot throughout the growing season. It is likely growers would only be able to attain the $206 \mathrm{~kg} \cdot \mathrm{ha}^{-1} \mathrm{~N}$ rate by using the BMPs associated with the 4-Rs Principles: right rate, right place, right source, and right timing (FDACS, 2015) and when weather related nutrient leaching is not a major factor. In situations where $\mathrm{N}$ would be broadcast applied with a ground applicator or applied via fertigation through an overhead irrigation system, the efficiency of those $\mathrm{N}$ applications would be much less than the bed-top-only placement used in this study. The $\mathrm{N}$ that is applied between the beds, especially early in the season when the carrot root system is not well developed, is much more vulnerable to being leached after high

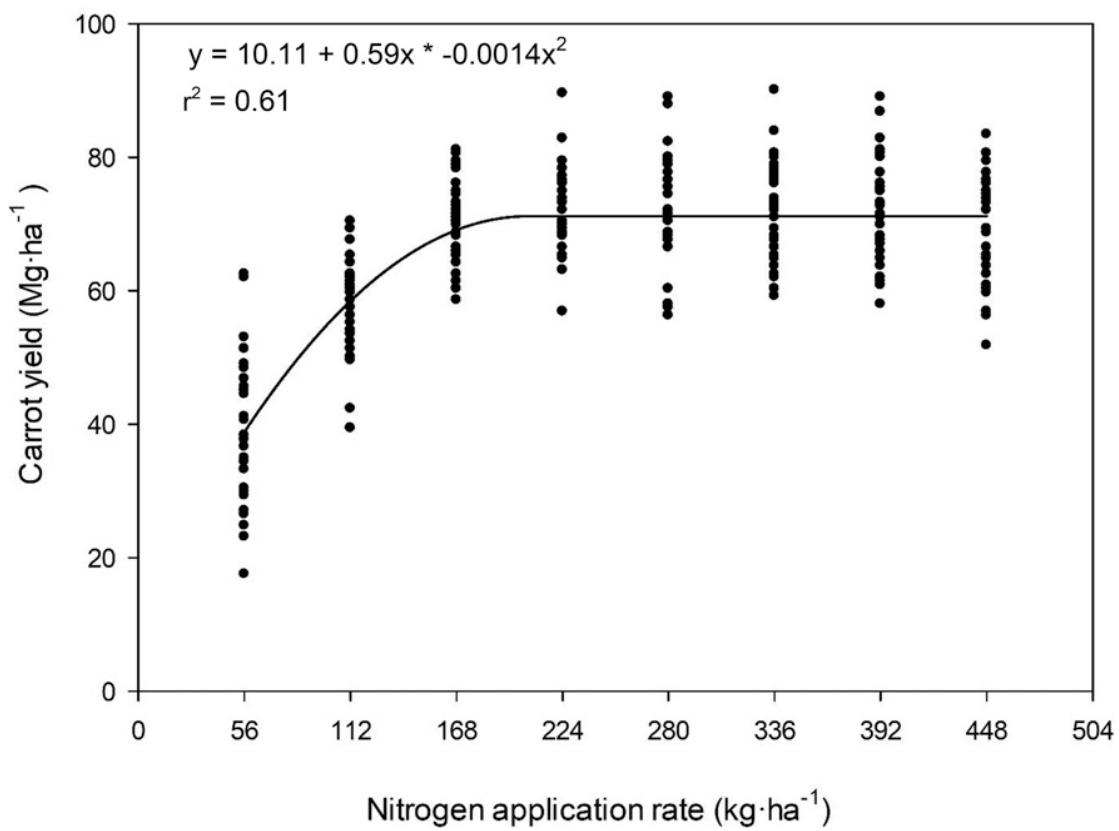

Fig. 2. Response of carrot marketable yield of four cultivars, to $\mathrm{N}$ fertilizer at eight application rates during the 2017 and 2018 growing seasons combined with quadratic plateau regression equation plotted. The equation and all parameters were significant at $P<0.0001$. 
irrigation or high rainfall events. Growers in the region use a variety of bed configurations and spacings, but most result in row middle or noncropped areas of at least $15 \%$ to $23 \%$ of the total cropland. Therefore, broadcast applications are not recommended, especially early in the crop season.

Irrigation during the season was managed by viewing soil moisture sensor data. Early in the season, the moisture is maintained in the top 20 to $30 \mathrm{~cm}$, but as the roots grow to their maximum depth of 30 to $40 \mathrm{~cm}$, the irrigation is managed to maintain adequate moisture to a depth of $40 \mathrm{~cm}$; however, care is taken not to have irrigation events that are too long, resulting in soil moisture moving past the $50 \mathrm{~cm}$ depth. Westerveld et al. (2006b) indicate that carrot roots efficiently uptake $\mathrm{N}$ below $30 \mathrm{~cm}$ depth. The observations of soil moisture sensor data in this trial suggest maturing carrots (75 to $90 \mathrm{~d}$ after seeding) can uptake water and nutrients to a depth of $40 \mathrm{~cm}$, but very little at $50 \mathrm{~cm}$. Therefore, we are confident that little or no $\mathrm{N}$ was lost from leaching events caused by irrigation because soil moisture was managed to a depth of $40 \mathrm{~cm}$.

In summary, cold injury, leaf $\mathrm{N}$ content, and carrot quality characteristics were minimally affected by $\mathrm{N}$ rate. All cultivars, for the whole carrot and the cut-and-peel markets, responded similarly to $\mathrm{N}$ fertilization and are suitable to North Florida carrot production with the exception of 'Uppercut 25' if a severe winter is forecasted. Carrot yield displayed a quadratic plateau response to increasing $\mathrm{N}$ fertilizer application rates. Yield was optimized at a $\mathrm{N}$ rate between 168 to 224 $\mathrm{kg} \cdot \mathrm{ha}^{-1}$ with a plateau of $71.3 \mathrm{Mg} \cdot \mathrm{ha}^{-1}$ beginning at $206 \mathrm{~kg} \cdot \mathrm{ha}^{-1} \mathrm{~N}$. Yield comparative to commercial producers was obtained at these $\mathrm{N}$ rates because specific BMPs were used to apply the right rate of fertilizer at the right time and place. Future work in carrots could explore the right source of $\mathrm{N}$ (i.e., controlled release) to determine whether fewer fertilizer applications could be made while maintaining yield and preventing $\mathrm{N}$ leaching.

\section{Literature Cited}

Farrar, J.J., B.M. Pryor, and R. Michael-Davis 2004. Alternaria diseases of carrot. Plant Dis. 88:776-784, doi: 10.1094/pdis.2004.88.8.776.

Florida Department of Agriculture and Consumer Services. 2015. Water quality/quantity best management practices for Florida vegetable and agronomic crops. Florida Dept. Agr. Consumer Serv., Tallahassee, FL.

Florida Department of Environmental Protection 2018. Suwannee River Basin management action plan (Lower Suwannee River, Middle Suwannee River, and Withlacoochee River Sub-basins). Florida Dept. Env. Protect., Tallahassee, FL.

Francis, D.M. 2013. Horsfall-Barratt scale: Quantitative evaluation of disease. eXtension articles. 2 Sept. 2019. <http://articles.extension.org/ pages/32452/horsfallbarratt-scale:-quantitativeevaluation-of-disease $>$.

Hamilton, H.A. and R. Bernier. 1975. N-P-K fertilizer effects on yield, composition and residues of lettuce, celery, carrot, and onion grown on an organic soil in Quebec. Can. J. Plant Sci. 55:453-461, doi: 10.4141/cjps75-071.

Hochmuth, G. and E. Hanlon. 2012. Calculating recommended fertilizer rates for vegetables growing in raised-bed, mulched cultural systems. University of Florida, Institute of Food and Agricultural Sciences. 2 Sept. 2019. <https://journals.flvc. org/edis/article/view/118053>, doi: 10.32473/ edis-ss516-2009.

Hochmuth, G.J., D. Maynard, C. Vavrina, E. Hanlon, and E. Simonne. 2018. Plant tissue analysis and interpretation for vegetable crops in Florida. University of Florida, Institute of Food and Agricultural Sciences. 2 Sept. 2019. $<\mathrm{https}: / /$ dis.ifas.ufl.edu/ep081 $>$.

Hochmuth, G.J., J.K. Brecht, and M.J. Bassett. 1999. Nitrogen fertilization to maximize carrot yield and quality on a sandy soil. HortScience 34:641-645, doi: 10.21273/hortsci.34.4.641.

Horsfall, J.G. and R.W. Barratt. 1945. An improved grading system for measuring plant diseases. Phytopathology 35:655.

Liu, G.D., E.H. Simonne, K.T. Morgan, G.J. Hochmuth, S. Agehara, and R. Mylavarapu. 2019. Fertilizer management for vegetable production in Florida, p. 3-9. In: P. Dittmar, J. Freeman, M. Paret, and H. Smith (eds.). Vegetable production handbook of Florida 2019-2020. AgNet Media, Gainesville, FL, doi: 10.32473/edis-cv100-2020.

Mangrum, M. 2016. Cautionary Tale: 20 years later, Lake Apopka is a 48-square-mile lesson in the importance of keeping pollution out of Florida's waters in the first place. WUFT, Project Blue Ether. 12 Oct. 2019. <https://www.wuft.org/ specials/water/lake-apopka-cautionary-tale/>.

Orlando Sentinel. 1985. A chronology: The growing role of vegetables. The Orlando Sentinel. 12 Oct. 2019. <https://www.orlandosentinel.com/news/ os-xpm-1985-08-12-0320160155-story.html>.

Paret, M. 2019. Carrot diseases, Alternaria leaf blight. U-scout program. University of Florida, Institute of Food and Agricultural Sciences. 10 Sept. 2019. <https://plantpath.ifas.ufl.edu/uscout/carrot/alternaria-leaf-blight.html $>$.

Sharma, V., C.E. Barrett, D. Broughton, and T. Obreza. 2020. Crop water use and irrigation scheduling guide for North Florida. 9 Sept. 2020 $<$ https://edis.ifas.ufl.edu/ss491>, doi: 10.32473/ edis-ss491-2020.

U.S. Department of Agriculture. 2019a. Data by commodity-imports and exports. U.S. Dept. Agr., Washington, D.C. 9 Sept. 2020. <https:// data.ers.usda.gov/reports.aspx?ID=17851>

U.S. Department of Agriculture. 2019b. Quick stats. U.S. Dept. Agr., Washington, D.C.

U.S. Department of Agriculture. 2019c. 2017 Census of agriculture. Florida, state and county data. U.S. Dept. Agr., Washington, D.C. 11 Sept. 2020. $<$ https://quickstats.nass.usda.gov/>.

U.S. Department of Agriculture. 1965. United States standards for grades of topped carrots. U.S. Dept. Agr., Washington, D.C.

Weatherspoon, R.L. 2006. Soil survey of Suwannee County, Florida. Washington, D.C.

Westerveld, S.M., A.W. McKeown, and M.R. McDonald. 2006a. Seasonal nitrogen partitioning and nitrogen uptake of carrots as affected by nitrogen application in a mineral and an organic soil. HortScience 41:1332-1338, doi: 10.21273/ hortsci.41.5.1332.

Westerveld, S.M., A.W. McKeown, and M.R. McDonald. 2006b. Distribution of nitrogen uptake, fibrous roots and nitrogen in the soil profile for fresh-market and processing carrot cultivars. Can. J. Plant Sci. 86:1227-1237, doi: 10.4141/p05-239.

Westerveld, S.M., M.R. McDonald, and A.W McKeown. 2006c. Carrot yield, quality, and storability in relation to preplant and residual nitrogen on mineral and organic soils. HortTechnology 16(2):286-293, doi: 10.21273/horttech.16.2.0286.

Westerveld, S.M., M.R. McDonald, and A.W. McKeown. 2007. Nitrogen utilization timeline of carrot over the growing season. Can. J. Plant Sci. 87:587-592, doi: 10.4141/p06-159. 